\title{
USING COLOR CODING TO IMPROVE STUDENTS' ENGLISH VOCABULARY ABILITY
}

\author{
Sandi Aryanto Asyid ${ }^{1}$, Dimas Muhamad Rizki Nurdiansyah ${ }^{2}$, Aseptiana Parmawati ${ }^{3}$ \\ ${ }^{1}$ IKIP Siliwangi \\ ${ }^{2}$ IKIP Siliwangi \\ ${ }^{3}$ IKIP Siliwangi \\ ${ }^{1}$ SandyAryantoAsyid@gmail.com, ${ }^{2}$ dimasmr01@gmail.com, ${ }^{3}$ aseptianaparmawati@gmail.com
}

\begin{abstract}
English is a subject in Indonesian school that learned from junior high school until the universities. Therefore one of importance basic aspects and skills in learning English for students is to understand a variety of English vocabulary. In learning English, vocabulary plays an important role, it means vocabulary is the basic one to mastering all English Skill. This research intended to students at seventh grade of Madrasah Tsanawiyah (MTs) in Cimahi. And this study aims to determine the benefits of Color Coding technique in improving the ability of English vocabulary. Color Coding is a method that can be used in teaching vocabulary, one of the use of color is to identifying something, it can make the student easy in their learning vocabulary process. The design of this research is Classroom Action Research (CAR). The researcher employed qualitative research design and pre experimental pretest-posttest. The data were collected from the result of pretest and posttets. The result of the data showed: Mean of pretest was 63.00, mean of posttest was 82.00, The result also show the score of $t$-observed was higher than $t-$ table $(2.08>1.72)$. It means color coding is effective to improve students' vocabulary ability.
\end{abstract}

Keywords: Vocabulary, Color Coding Technique, CAR

\section{INTRODUCTION}

Nowdays English language as the international Language and used by elements of people in over the world especially in Indonesia. In the era of globalization, learning English is very important because English able for linking and make easily people in the most of countries are communicated each other based on the development in the field of economic, business, education and also politic, Parmawati (2018). The government of Indonesia and minister of education are taught from primary school this is the key of find out to introducing English language to be generally in Indonesia.

Vocabulary is generically defined as the knowledge of words and word meanings. More specifically, we use vocabulary to refer to the kind of words that students must know to read increasingly demanding text with comprehension (Hiebert, 2005). Basic aim of language learning nowdays is communication and vocabulary plays an important role in conversation (Komorowska, 2005). According both of experts we can know about important of English vocabulary for each elements people actually the learned who the learning English study, from learning basic vocabulary the students will be ready to begin learn English with kind of technique or method. Learning English is easy for students when they find comfort environment and maked enjoy athmophere in the classroom. 
Through this study the researcher wanted to examine a technique which is hoped can be a good method for teaching vocabulary to the students in Madrasah Tsanawiyah or Junior High School level. Here the researcher tried to present Color Coding technique to the students in Madrasah Tsanawiyah or Junior High School level. Teaching English vocabulary using Color Coding (CC) technique can be considered as one of the appropriate methods. In teaching to the Madrasah Tsanawiyah or Junior High Sschool level students, the teacher had be more enjoy and be able to keep the students away from getting bored in learning English vocabulary.

People use color in various ways. The idea of identifying something by a specific color is to alleviate affect, "Color coding would seem to be ideal for this. People use color coding from infancy for identifying ownership of states in a process, the color of traffic lights, for example, are a code system. We all have concepts linked to colors, and the use of color indicate the increase or decrease familiar to our students" (Engelbrecht, 2003). Certain colors indicate or decrease one's affect given how the color is being interpreted at that moment.

\section{METHOD}

In this research, the researcher used Classroom Action Research (CAR). (Kemmis, 1983) in (Hopkins, 1993) states that action research is trying out an idea in practice with a view to improving or changing something, trying to have a real effect on the situation. CAR is a research to solve the problems usually done by teacher. Action research is a process in which participants examine their own educational practice systematically and carefully using the techniques of research based on the following assumptions:

1. Teachers and principals work best on problems they have identified for themselves;

2. Teachers and principals become more effective when encouraged to examine and assess their own work and then consider ways of working differently;

3 . Teachers and principals help each other by working collaboratively;

4. Working with colleagues helps teachers and principals in their professional development (Watts, 1985).

Besides, Burns, cited in Cornwell action research involves a self- reflective, systematic and critical approach to enquiry by participants who are at the same time members of the research community. The aim is to identify problematic situations or issues considered by participants to be worthy of investigation in order to bring about critically informed changes in practice (Burns, 1999). Meanwhile, Anna Uhl Chamot et al define that action research is classroom based research conducted by teachers in order to reflect upon and evolve their teaching. It is a systematic, documented inquiry into one aspect of teaching and learning in a specific classroom. The purpose of teacher research is to gain understanding of teaching and learning within one's classroom and to use that knowledge to increase teaching efficacy/student learning.

The Model of action research is developed by (McTaggart, 1988) consisting four aspects.

1. Planning: develop a plan of critically informed action to improve what is already happening.

2. Action: act to implement the plan.

3. Observation: observe the effects of the critically informed action in the context in which it occurs.

4. Reflection: reflect on these effects as the basis for further planning, subsequent, critically informed action [etc.] through succession of stages (McTaggart, 1988). 
The writer conducts pre-test and posttest as the instrument of the research.

In one-group-posttest design a single group of subjects is given a pretest $(\mathrm{O})$, then the treatment $(\mathrm{X})$, and then the posttest $(\mathrm{O})$. In the research, the techniques used for collecting the data are qualitative data.

\section{a. Pre-test}

Pre-test was used before the treatment to measure how far students could comprehend the text they read and to gain the score as well.

\section{b. Treatment}

The treatment in this research used extensive reading approach. The treatment was given after the pre-test.

\section{c. Post-test}

The posttest was used to determine the students' vocabulary ability after giving the treatment. The form of the posttest was same as pretest form. The score of post-test would be compared with the score of pre-test.

\section{RESULTS AND DISCUSSION}

\section{Results}

The result of the research was obtained through pre-test and post-test. Pre-test was conducted before the treatment while post-test was performed after the treatment. The result of students' pre-test and post-test as follows:

Table 1. The result of pretest and posttest

\begin{tabular}{cccccc} 
No. & Name & Pretest Score & Posttest Score & $\boldsymbol{\Sigma} \boldsymbol{D}$ & $\boldsymbol{\Sigma} \boldsymbol{D}^{\mathbf{2}}$ \\
\hline 1 & Student 1 & 80 & 90 & 10 & 100 \\
\hline 2 & Student 2 & 70 & 80 & 10 & 100 \\
\hline 3 & Student 3 & 50 & 80 & 30 & 900 \\
\hline 4 & Student 4 & 90 & 100 & 10 & 100 \\
\hline 5 & Student 5 & 60 & 80 & 20 & 400 \\
\hline 6 & Student 6 & 70 & 80 & 20 & 400 \\
\hline 7 & Student 7 & 60 & 80 & 10 & 100 \\
\hline 8 & Student 8 & 50 & 90 & 40 & 1600 \\
\hline 9 & Student 9 & 60 & 80 & 20 & 400 \\
\hline 10 & Student 10 & 80 & 90 & 10 & 100 \\
\hline 11 & Student 11 & 80 & 90 & 10 & 100 \\
\hline 12 & Student 12 & 60 & 80 & 20 & 400 \\
\hline 13 & Student 13 & 70 & 80 & 10 & 100 \\
\hline 14 & Student 14 & 80 & 90 & 10 & 100 \\
\hline 15 & Student 15 & 40 & 70 & 30 & 900 \\
\hline 16 & Student 16 & 60 & 80 & 20 & 400 \\
\hline 17 & Student 17 & 40 & 70 & 30 & 900 \\
\hline 18 & Student 18 & 60 & 80 & 20 & 400 \\
\hline & & & & &
\end{tabular}




\begin{tabular}{cccccc}
19 & Student 19 & 60 & 80 & 20 & 400 \\
\hline 20 & Student 20 & 40 & 70 & 30 & 900 \\
\hline & Total & 1420 & 1690 & 380 & 8800 \\
\hline
\end{tabular}

Based on the data above, the result of scores was:

\section{Mean Score of Pre-test}

$x=63$

Mean Score of Post-Test

$x=82$

Standard Deviation Score of Pre-test

$\mathrm{SD}=\sqrt{\frac{8800-\left(\frac{1}{20}\right)(380)^{2}}{19}}$

$\mathrm{SD}=\sqrt{\frac{1580}{19}}=\sqrt{83.15}$

$\mathrm{SD}=9.12$

\section{T-Test}

$$
\mathrm{t}=\frac{63-82}{9.12}=2.08
$$

The critical value of t-table with df (degree of freedom) 19 and the level of significance at 0.05 was 1.72 . The $t$-test calculation is 2.08 . It means $t_{\text {obs }}$ is higher than $t_{\text {table }}(2.08>1.72)$.

\section{Discussion}

In this research the writer used pre-test and post-test as the instruments to collect the data. The writer gave the pre-test before the writer did the treatment using the method and gave the posttest after the treatment.

To prove this research reliable or not, writer chose the research object as the evidence. The writer chose the students of MTs Cimahi. Johnson in (Suprijadi, 2016) defines that population as "the entire group of entities or persons to which the result of a study is intended to apply". The population in this research was the seventh grade of MTs Cimahi in the academic year 2017/2018. The population of the research consisted of 20 students.

The writer took the sample for the research. "Sample is the smaller group which is a portion of a population" (Tavakoli, 2012). The sample of this research was the entire of the population that was seventh grade of A class. The number of the sample was 20 students.

The writer started the research on 29 January until 12 February 2018. The research was applied on 3 meetings and the duration for each meeting and test were 45 minutes. In this case, the researcher tried to use one class consists of 20 students at the seventh grade of MTs Cimahi in the academic year 2017/2018.

In this research, the researcher used tests to collect the data, they were pre-test and post-test. The test was given before and after the treatment. The test in this research was multiple choice tests that consisted 20 items of multiple choice questions. 


\section{CONCLUSION}

Vocabulary is a crucial thing that students have to mastery, the researcher want to improve that teaching vocabulary through color coding can improve students' vocabulary mastery, it is occur based on the problems that students faced in the field that was students have a trouble in memorizing vocabulary, and in this case teacher is demanded to creative make a learning process is more attractive, and it has really proved by the result of the research which was color coding can improve students' vocabulary

The result of this research showed that the vocabulary ability of the 7th grade of students at MTs in Cimahi taught using color coding were better than those who learned without using color coding. This finding indicates that a lesson using color coding for teaching vocabulary could improve students' ability in vocabulary. Color coding can help the writer in teaching learning process more interesting. Color coding can motivate students more and helped them create ideas and feeling, because they knew more vocabulary.

Besides, the researcher also finds that the implementation of color coding technique got positive responses from students in their teaching-learning process of vocabulary, they like the technique because the technique make them better in memorizing and do some fun in learning, it was not make them stressed and boring during teaching- learning activity.

Finally, the researcher hopes that this research will give a contribution to the readers in order to use the strategy which is appropriate in teaching vocabulary process, and can be an additional reference for those who are interested in learning more about strategy of teaching vocabulary and also in making further study on similar topic.

\section{ACKNOWLEDGMENTS}

This article is the result of hard work, guidance, and support from several people. Thus, we would like to proclaim our honor to our supervisor, parents, beloved one, and people who have given their support, prayers, and guidance in writing this article. We also would like to give an appreciation of gratitude to IKIP Siliwangi, the head of English Education Study Program, and the lecturers in English Education Study Program who have given us knowledge, supervision, and time for the last three and a half year. Finally, the writer hope this article will have some contributions and be helpful to the audiences of PROJECT (Professional Journal of English Education) no matter how small and deficient it is. The suggestions and critics are welcomed.

\section{REFERENCES}

Burns. (1999). Collaborative action research for English language teachers. 5. Cambridge: Cambridge University Press

Engelbrecht. (2003). Changing roles for education support professionals. 3. In: Engelbrecht L, Engelbrecht P, Green L, Naicker S, (editors). Inclusive Education in Action in South Africa. South Africa: Van Schaik Publishers, 2003.

Hiebert, K. \&. (2005). Current Research On Vocabulary Instruction.

Hopkins. (1993). A Teacher's Guide to Classroom Research. Buckingham: Open University Press., 45.

Kemmis. (1983). A Teacher's Guide to Classroom Research. Buckingham: Open University Press.

Komorowska. (2005). Metodyka Nauczania Języków Obcych. Warszawa: Fraszka Edukacyjna, 151. 
McTaggart, K. and. (1988). The Action Research Planner, 3rd edn. Waurn Ponds: Deakin University Press., 10.

Parmawati, A. (2018). Using Analytic Teams Technique To Improve Students'speaking Skill. Edulitics (Education, Literature, And Linguistics) Journal, 3(2), 21-25.

Suprijadi, K. and. (2016). Metode dan teknik penulisan karya ilmiah. Edisi 2 (2015) Revisi 1 (2016). Bandung: STKIP SILIWANGI Press.

Tavakoli. (2012). A Dictionary of Research Methodology and Statistic in Applied Linguistic. Tehran: Rahnama Press.

Watts, H. (1985). When Teachers are Researchers, Teaching Improves. Journal of Staff Development, 6 (2), 118-127. 